\title{
Diet effects on enterocyte development
}

\author{
BY MICHAEL W. SMITH \\ Department of Cell Biology, AFRC Institute of Animal Physiology and Genetics Research, \\ Babraham, Cambridge CB2 4AT
}

Enterocytes produced in intestinal crypts express a genetically determined programme of development during migration towards the tips of villi which is also influenced by environmental factors such as diet. Delayed weaning, for instance, reduces the amount of sucrase (EC 3.2.1.48) appearing in the small intestine (Henning, 1985) and changing the diet of adult animals affects the ability of enterocytes to absorb amino acids (Dauncey et al. 1983; King et al. 1983; Cremaschi et al. 1986). A major difficulty encountered in analysing these effects arises, however, from the fact that dietary change often affects crypt cell proliferation, either by altering the level of luminal nutrition or by changing the rate at which pancreaticobiliary secretions appear in the gut (Dowling, 1982). Use of isoenergetic diets will not control this variable when the substituted component is poorly metabolized (Smith et al. 1990a). Routine measurement of proliferative status (Al-Mukhtar et al. 1981) and enterocyte turnover (Leblond, 1991) should be carried out whenever possible to eliminate or quantify possible trophic effects of diet on intestinal function. Enterocytes change their structure and their ability to digest and absorb nutrients during maturation, and differentiation of some of these properties takes place sequentially in fetal as well as adult intestine (see Smith, 1985, 1991). Modern techniques of immunocytochemistry (Shields et al. 1986; Sweetser et al. 1988) enzyme cytochemistry (Gossrau, 1980; James et al. 1988; Tivey \& Smith, 1989), autoradiography (King et al. 1983; Smith et al. 1983) and in situ hybridization (Boller et al. 1988; Kiyama et al. 1991) now make it possible to assess quantitatively how diet affects the expression of these different functions in villus-attached enterocytes.

\section{DIET MANIPULATION OF ENTEROCYTE DEVELOPMENT}

Enterocyte brush-border membranes cause a twenty-sixtyfold increase in villus surface area when fully developed and all this surface is potentially available for the terminal digestion of nutrients (Ferraris et al. 1989; Smith et al. 1990b). Increasing the amount of food eaten or changing the protein content of isoenergetic diets changes the ability of enterocytes to develop this cell surface structure (Smith et al. 1984). Mathematical analysis of growth curves describing this development allows one to formulate a simple equation describing microvillus formation having the form $\mathrm{M}=0.0016 \mathrm{CD}+0.073$ $\mathrm{CD} / \mathrm{R}$, where $M$ is the maximal microvillus length, $C D$ is the crypt depth $(\mu \mathrm{m})$ and $R$ is the enterocyte migration rate $(\mu \mathrm{m} / \mathrm{h}$; Smith \& Brown, 1989). Slowing enterocyte migration rates to values less than $6 \mu \mathrm{m} / \mathrm{h}$ causes a big increase in $M . C D$ is the main determinant of brush-border formation at high migration rates.

Increasing the sugar content of diets induces enterocyte expression of sucrase and maltase (EC 3.2.1.20; see Cézard et al. 1983). Further investigation of this response has been carried out to identify common features controlling disaccharidase expression. Mice fed on glucose, fructose, 3-0-methyl-glucose or a diet low in carbohydrate were 


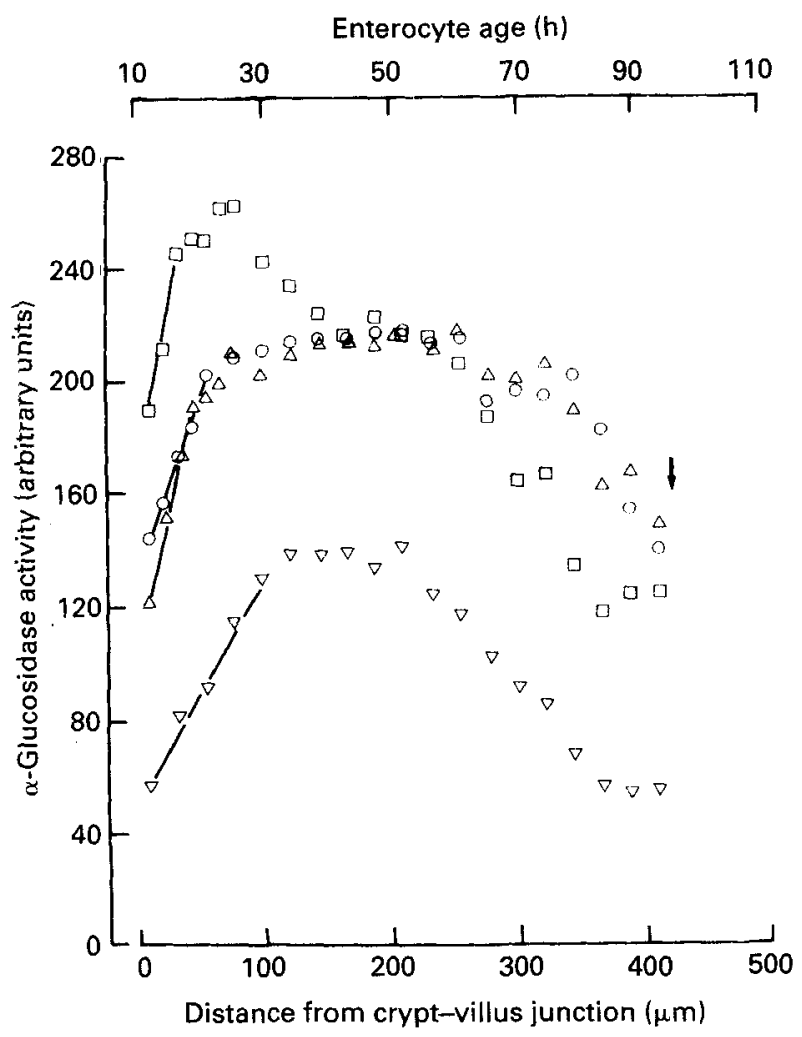

Fig. 1. Effect of sugars on $\alpha$-glucosidase (EC 3.2.1.20) expression by mouse jejunal enterocytes. Mice were fed on a low-carbohydrate diet $(\nabla)$, isoenergetic diets containing glucose or fructose $(O, \Delta)$ or a low-carbohydrate diet to which was added 3-0-methyl-glucose $(\square)$ to maintain food intake, body-weight and enterocyte migration rates constant.

used to determine the time dependency of $\alpha$-glucosidase (maltase + sucrase) expression during enterocyte migration along intestinal villi. The amount of enzyme reaction product formed by hydrolysis of a synthetic substrate was determined in the brushborder membrane by microdensitometry (Collins et al. 1989). The results obtained from these experiments are summarized in Fig. 1.

Enzyme activity increases rapidly to reach a plateau as enterocytes begin to migrate over the lower parts of villi. Activity then falls as enterocytes continue to migrate towards the tips of villi. Maximal expression of $\alpha$-glucosidase activity here can be calculated as RT where $\mathrm{R}$ is the initial rate of enzyme expression and $\mathrm{T}$ is the time during which $\mathrm{R}$ operates. An inverse relationship existing between $\mathrm{R}$ and $\mathrm{T}$ (Fig. 1) implies some inherent limitation in the capacity of individual enterocytes to adapt. Lactase $(E C$ 3.2.1.108) activity determined cytochemically in serial sections of the same tissues is not affected by changes in diet.

Maximal expression of $\alpha$-glucosidase and microvillus growth takes place in young enterocytes as they migrate from crypts onto villi. First appearance of amino acid transport on the other hand only occurs in the upper regions of villi (King et al. 1983; Cremaschi et al. 1986). This ability to transport amino acids then increases linearly up to 
the time cells leave the villus. This suggests that the genetic programme controlling this function has not had time to reach completion. Exceptions to this might occur in the neonate where villi are particularly long and enterocyte migration rates much reduced (Klein \& McKenzie, 1983). Placing rats on an isoenergetic diet containing $200 \mathrm{~g}$ protein $/ \mathrm{kg}$ instead of $5 \mathrm{~g}$ protein $/ \mathrm{kg}$ increases amino acid transport by increasing villus size (King et al. 1983). Reducing food intake does the same by reducing enterocyte migration rate (Cremaschi et al. 1986; Thompson \& Debnam, 1986). A similar positional dependence of peptide uptake can also be changed by feeding animals a low-protein diet (Cheeseman, 1986).

The previous results provide examples of how dietary change affects the biosynthesis of single or multiple gene products at different stages of enterocyte development. Further work tests whether such gene expression is subject to pre- or post-translational control by relating gene products to mRNA concentrations in the same enterocyte. Initial experiments using in situ hybridization show mRNA concentrations for both villin and sucrase-isomaltase (EC 3.2.1.10) to be highest in enterocytes near the crypt-villus junction suggesting that this is the most likely site for activation of villin and sucraseisomaltase expression (Boller et al. 1988; Traber, 1990). Injection of vitamin D into chickens raised on a vitamin D-deficient diet allows one to study the ability of individual enterocytes to produce calbindin mRNA and calbindin protein from negligible starting levels. Calbindin mRNA in this case appears to be inefficiently translated in basal villus enterocytes with all other enterocytes exerting a pretranslational control over calbindin synthesis (Kiyama et al. 1991). Enterocytes emerging from crypts may be required to make many gene products in a short space in time and this could create an as yet unspecified rate-limiting step in protein biosynthesis.

\section{LACTASE EXPRESSION BY DEVELOPING ENTEROCYTES}

Lactase biosynthesis differs from that of other brush-border hydrolases by being formed initially as a large precursor which is cleaved intracellularly (Naim et al. 1987) before being anchored to the brush-border membrane by a hydrophobic segment located in the C- rather than the $\mathrm{N}$-region of the molecule (Mantei et al. 1988). The time taken to complete biosynthesis is also considerably longer than that taken for other brush-border enzymes (Hauri et al. 1985). Regulation of lactase biosynthesis also appears to be more complicated than that reported for other enzymes, adults showing an anomalous increase in mRNA at a time when lactase activity remains low (Sebastio et al. 1989). Post-weaning decreases in lactase activity have been described previously as resulting from reduced lactase synthesis (Jonas et al. 1985) or a more rapid replacement of existing enterocytes (Tsuboi et al. 1985). Combining cytochemical estimates of lactase activity with separate measurements of enterocyte migration rate identifies two ways in which lactase biosynthesis is down-regulated (Smith \& James, 1987). The results of these experiments are shown in Fig. 2.

Lactase activity is much greater in 15-d-old compared with 23 - and 46-d-old rats. Activity in the 23-d-old rat is also slightly greater than that found in 46-d-old animals (Fig. 2 (a)). Enterocyte migration rates increase from $2.6 \mu \mathrm{m} / \mathrm{h}$ in 15 -d-old rats to 10.9 and $12.5 \mu \mathrm{m} / \mathrm{h}$ in 23 - and $46-\mathrm{d}$-old rats respectively. Plotting this data on a real-time basis (Fig. 2 (b)) shows the fall in lactase activity at $23 \mathrm{~d}$ to occur without change in the rate of lactase biosynthesis. The further decline in the 46-d-old rat is due to a decline in the rate 

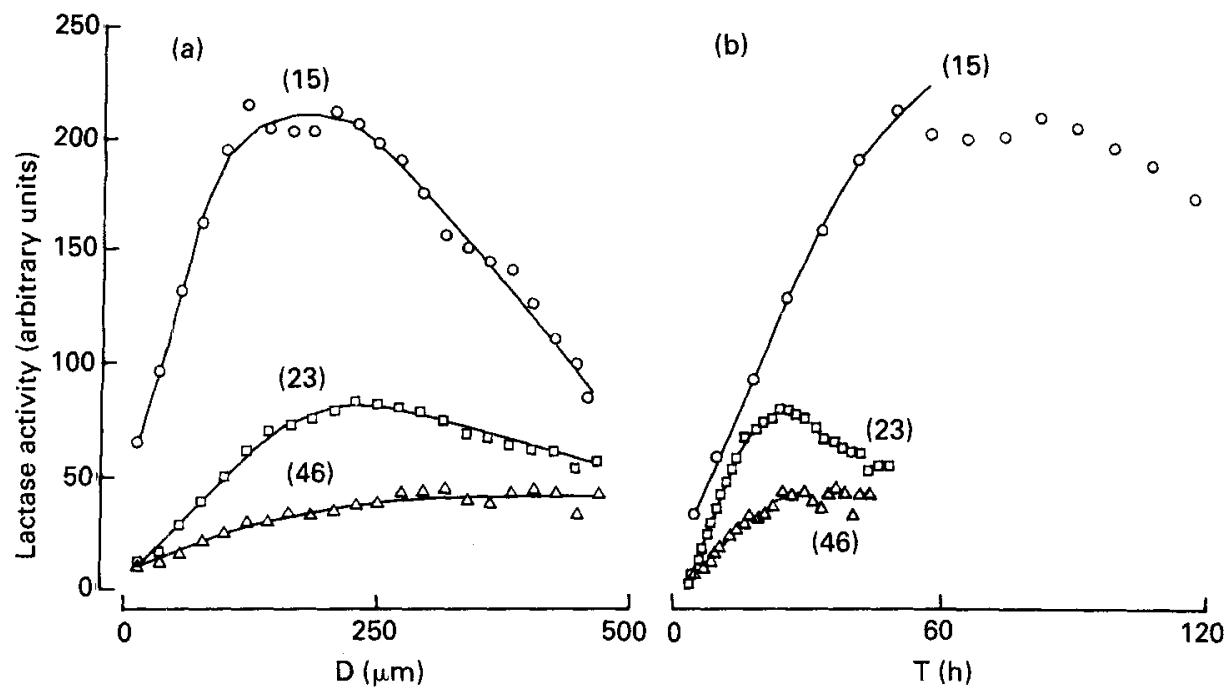

Fig. 2. Developmental profiles for lactase ( $E C$ 3.2.1.108) appearance in brush-border membranes of rat jejunal enterocytes measured during postnatal development. Lactase activity determined cytochemically is related to (a) the enterocyte distance $D$ from the crypt and (b) the age of the enterocyte $T$. Values in parentheses are the age of rats.

of lactase biosynthesis. The initial fall in lactase activity probably results from increased crypt cell proliferation. The later decline in activity possibly occurs as a secondary consequence of immune reactions operating in apparently healthy animals (Phillips et al. 1987).

Both dietary composition and metabolizable energy can affect enterocyte differentiation. Preliminary attempts to distinguish these variables involve feeding galactosecontaining and galactose-free diets to mice. The effect these treatments have on the in vivo expression of lactase as well as other markers of enterocyte differentiation is shown in Table 1. Maximal expression of six markers of enterocyte differentiation were

Table 1. Diet modification of enterocyte differentiation

\begin{tabular}{lccc}
\hline & \multicolumn{3}{c}{ Diet } \\
\cline { 2 - 4 } & $\begin{array}{c}\text { Galactose } \\
+ \text { energy } \\
(21.7 \mathrm{~kJ} \\
(5 \cdot 2 \mathrm{kcal}) / \mathrm{g})\end{array}$ & $\begin{array}{c}\text { Galactose } \\
(12 \cdot 9 \mathrm{~kJ} \\
(3 \cdot 1 \mathrm{kcal}) / \mathrm{g})\end{array}$ & $\begin{array}{c}\text { Energy } \\
(12 \cdot 9 \mathrm{~kJ} \\
(3 \cdot 1 \mathrm{kcal}) / \mathrm{g})\end{array}$ \\
\hline Enterocyte marker & & & \\
Sucrase $(E C$ 3.2.1.48)-maltase & 163 & 165 & 100 \\
$\quad(E C$ 3.2.1.20) & 173 & 191 & 100 \\
Microvillus & 119 & 156 & 100 \\
Dipeptidylpeptidase IV $(E C$ 3.4.14.5) & 97 & 213 & 100 \\
Aminopeptidase N $(E C 3.4 .11 .2)$ & 95 & 92 & 100 \\
Alkaline phosphatase $(E C$ 3.1.3.1) & 106 & 67 & 100 \\
Lactase $(E C$ 3.2.1.108) & $5 \cdot 1$ & $2 \cdot 5$ & 6.5 \\
Enterocyte migration & & & \\
\hline
\end{tabular}


normalized to give a value of 100 in mice fed on a low-carbohydrate diet (energy in Table 1). Substituting galactose for maize oil increases the expression of four of these markers with alkaline phosphatase (EC 3.1.3.1) remaining unchanged and lactase expression being inhibited. Galactose is poorly metabolized by mice and this caused a two-threefold inhibition in enterocyte migration rate. Providing a diet containing the same amount of galactose plus maize oil (galactose + energy in Table 1) does not change the ability of galactose to increase sucrase-maltase or microvillus membrane expression, but it does remove the inhibitory effect galactose imposed previously on lactase expression. Enterocyte migration rate is maintained at near normal levels under these conditions. It is concluded from these results that galactose can act selectively to induce sucrasemaltase and microvilius membrane development but that its inhibitory effect on lactase biosynthesis is secondary to changes taking place in energy availability (Smith et al. 1991). Galactose present in milk as lactose could produce some of these effects in neonatal animals. This possibility is being currently investigated by feeding different mixtures of galactose-glucose-containing isoenergetic diets to adult mice.

\section{REFERENCES}

Al-Mukhtar, M. Y. T., Polak, J. M., Bloom, S. R. \& Wright, N. A. (1981). The search for appropriate measurements of proliferative and morphological status in studies on intestinal adaptation. In Mechanisms of Intestinal Adaptation, pp. 3-25 [J. W. L. Robinson, R. H. Dowling and E.-O. Riecken, editors]. Lancaster: MTP Press Ltd.

Boller, K., Arpin, M., Pringault, E., Mangeat, P. \& Reggio, H. (1988). Differential distribution of villin and villin mRNA in mouse intestinal epithelial cells. Differentiation 39, $51-57$.

Cézard, J. P., Broyart, J. P., Cuisinier-Gleizes, P. \& Mathieu, H. (1983). Sucrase-isomaltase regulation by dietary sucrose in the rat. Gastroenterology $84,18-25$.

Cheeseman, C. I. (1986). Expression of amino acid and peptide transport systems in rat small intestine. American Journal of Physiology 251, G636-G641.

Collins, A. J., James, P. S. \& Smith, M. W. (1989). Sugar-dependent selective induction of mouse jejunal disaccharidase activities. Journal of Physiology 419, 157-167.

Cremaschi, D., James, P. S., Meyer, G., Rossetti, C. \& Smith, M. W. (1986). Intracellular potassium as a possible inducer of amino acid transport across hamster jejunal enterocytes. Journal of Physiology 375, 107-119.

Dauncey, M. J., Ingram, D. L., James, P. S. \& Smith, M. W. (1983). Modification by diet and environmental temperature of enterocyte function in piglet intestine. Journal of Physiology 341, 441-452.

Dowling, R. H. (1982). Small bowel adaptation and its regulation. Scandinavian Journal of Gastroenterology 17, Suppl. 74, 53-74.

Ferraris, R. P., Lee, P. P. \& Diamond, J. M. (1989). Origin of regional and species differences in intestinal glucose uptake. American Journal of Physiology 257, G689-G697.

Gossrau, R. (1980). Conventional techniques for membrane-bound enzymes. Ciba Foundation Symposium 73, $67-80$.

Hauri, H.-P., Sterchi, E. E., Bienz, D., Fransen, J. A. M. \& Marxer, A. (1985). Expression and intracellular transport of microvillus membrane hydrolases in human intestinal epithelial cells. Journal of Cell Biology 101, 838-851.

Henning, S. J. (1985). Ontogeny of enzymes in the small intestine. Annual Review of Physiology 47, 231-249.

James, P. S., Smith, M. W. \& Tivey, D. R. (1988). Single-villus analysis of disaccharidase expression by different regions of the mouse intestine. Journal of Physiology 401, 533-545.

Jonas, M. M., Montgomery, R. K. \& Grand, R. J. (1985). Intestinal lactase synthesis during postnatal development in the rat. Pediatric Research 11, 956-962.

King, I. S., Paterson, J. Y. F., Peacock, M. A., Smith, M. W. \& Syme, G. (1983). Effect of diet upon enterocyte differentiation in the rat jejunum. Journal of Physiology 344, 465-481.

Kiyama, H., Wu, J. C. Y., Smith, M. W., Lawson, E. D. M. \& Emson, P. C. (1991). Developmental control over Vitamin-D-induced calbindin gene expression during early differentiation of chicken enterocytes. Differentiation 46, 69-73. 
Klein, R. M. \& McKenzie, J. C. (1983). The role of cell renewal in the ontogeny of the intestine. I. Cell proliferation patterns in adult, fetal, and neonatal intestine. Journal of Pediatric Gastroenterology and Nutrition 2, $10-43$.

Leblond, C. P. (1991). Time dimension in cell biology. A radioautographic survey of the dynamic features of cells, cell components, and extracellular matrix. Protoplasma 160, 5-38.

Mantei, N., Villa, M., Enzler, T., Wacker, H., Boll, W., James, P., Hunziker, W. \& Semenza, G. (1988). Complete structure of human and rabbit lactase-phlorizin hydrolase: implications for biosynthesis, membrane anchoring and evolution of the enzyme. EMBO Journal 7, 2705-2713.

Naim, H. Y., Sterchi, E. E. \& Lentze, M. J. (1987). Biosynthesis and maturation of lactase-phlorizin hydrolase in the human small intestinal epithelial cells. Biochemical Journal 241, 427-434.

Phillips, A. D., Smith, M. W. \& Walker-Smith, J. A. (1987). Selective alteration of brush-border hydrolases in intestinal diseases in childhood. Clinical Science 74, 193-200.

Sebastio, G., Villa, M., Sartorio, R., Guzzetta, V., Poggi, V., Auricchio, S., Boll, W., Mantei, N. \& Semenza, G. (1989). Control of lactase in human adult-type hypolactasia and in weaning rabbits and rats. American Journal of Human Genetics 45, 489-497.

Shields, H. M., Bates, M. L., Bass, N. M., Best, C. J., Alpers, D. H. \& Ockner, R. K. (1986). Light microscopic immunocytochemical localization of hepatic and intestinal types of fatty acid-binding proteins in rat small intestine. Journal of Lipid Research 27, 549-557.

Smith, M. W. (1985). Expression of digestive and absorptive function in differentiating enterocytes. Annual Review of Physiology 47, 247-260.

Smith, M. W. (1991). Cell biology and molecular genetics of enterocyte differentiation. Current Topics in Membrane Transport 39, 153-179.

Smith, M. W. \& Brown, D. (1989). Dual control over microvillus elongation during enterocyte development. Comparative Biochemistry and Physiology 93A, 623-628.

Smith, M. W. \& James, P. S. (1987). Cellular origin of lactase decline in postweaned rats. Biochimica et Biophysica Acta 905, 503-506.

Smith, M. W., James, P. S. \& Collins, A. J. (1990a). Galactose inhibits lactase expression by mouse jejunal enterocytes. Biochimica et Biophysica Acta 1051, 109-111.

Smith, M. W., James, P. S. \& Peacock, M. A. (1991). Galactose effects on enterocyte differentiation in the mouse jejunum. Biochimica et Biophysica Acta 1093, 144-146.

Smith, M. W., Mitchell, M. A. \& Peacock, M. A. (1990b). Effects of genetic selection on growth rate and intestinal structure in the domestic fowl (Gallus domesticus). Comparative Biochemistry and Physiology 97A, 57-63.

Smith. M. W., Paterson, J. Y. F. \& Peacock, M. A. (1984). A comprehensive description of brush border membrane development applying to enterocytes taken from a wide variety of mammalian species. Comparative Biochemistry and Physiology 77A, 655-662.

Smith, M. W., Sepúlveda, F. V. \& Paterson, J. Y. F. (1983). Cellular aspects of amino acid transport. In Intestinal Transport, pp. 46-63 [M. Gilles-Baillien and R. Gilles, editors]. Berlin: Springer Verlag.

Sweetser, D. A., Hauft, S. M., Hoppe, P. C., Birkenmeier, E. H. \& Gordon, J. I. (1988). Transgenic mice containing intestinal fatty acid-binding protein human growth hormone fusion genes exhibit correct regional and cell-specific expression of the reporter gene in their small intestine. Proceedings of the National Academy of Sciences USA 85, 9611-9615.

Thompson, C. S. \& Debnam, E. S. (1986). Starvation-induced changes in the autoradiographic localisation of valine uptake by the rat small intestine. Experientia 43, $945-948$.

Tivey, D. R. \& Smith, M. W. (1989). Cytochemical analysis of single villus peptidase activities in pig intestine during neonatal development. Histochemical Journal 21, 601-608.

Traber, P. G. (1990). Regulation of sucrase-isomaltase gene expression along the crypt-villus axis of rat small intestine. Biochemical and Biophysical Research Communications 173, 765-773.

Tsuboi, K. K., Kwong, L. K., D’Harlingue, A. E., Stevenson, D. K., Kerner, J. A. \& Sunshine, P. (1985). The nature of maturational decline in intestinal lactase activity. Biochimica et Biophysica Acta 840, 69-78. 